\title{
CHIŃSKIE NAZWY RELIGIJNE I ZABOBONNE
}

Słow a te ma ty c zn e: chińskie toponimy zabobonne i religijne, chińskie geograficzne nazwy życzeniowe, toponimia chińska

W kulturze chińskiej związek pomiędzy nazwą a rzeczywistością był uważany nie za formalny czy idealny, lecz rzeczywisty i bardzo ważny. Podejście do nazw jako do rzeczywistych faktów sprawiło, że Chińczycy często ujawniali swe kulturowo nacechowane pragnienia, tworząc celowo i z rozwagą nazwy oznaczające odpowiednie idee. Wiele chińskich nazw geograficznych zostało świadomie nadanych w celu wywołania pożądanych z punktu widzenia dawcy nazwy efektów w przyszłości, wyrażając dążenie do szczęścia, nadzieję na uzyskanie patronatu czy opieki sił nadnaturalnych, promując słuszne postawy czy cechy moralne lub też po prostu oddziałując na innych tym, że nazwy te były uznane za dobre, atrakcyjne czy inspirujące.

\section{NAZWY ŻYCZENIOWE}

Nazwy geograficzne, pełniące w komunikacji społecznej funkcję magiczną, mające kreować przyszłość, w zachodniej literaturze toponomastycznej określa się jako nazwy życzeniowe, pochwalne czy dobrowróżebne (ang. commendatory names (Stewart 1970: XXX-XXXI; Stewart 1975: 85-88, 127-131), wishful names, benedictory names czy auspicious names (TNEB 1974: 819; 1994: 737)).

Chińskie terminy stosowane dla tego typu nazw są równie liczne, ale najczęściej występujące to: mei ming 美名 'dobre nazwy' (Chen 1979: 12), meiyuan diming 美願 地名 'nazwy geograficzne dobrych intencji' (Liu 1984: 48-51), shiyi diming 示意地名 'nazwy geograficzne wyrażające idee/intencje' (Chen 1982: 233-234), yin jia yan er ming de diming 因嘉言而名的地名 'nazwy geograficzne zawierające dobre słowa' (Liu 1979: 20).

Główne cechy takich nazw geograficznych - toponimów, nazywanych tu życzeniowymi — zostały określone przez G. R. Stewarta (1970: XXX-XXXI; 1975: 85-88, 127-131). Poniżej przedstawiono najważniejsze z nich. 
(1) Nazwy życzeniowe muszą być nadane świadomie i celowo, tzn. w określonym czasie przez określonego dawcę czy dawców w pełni świadomości, że taka nazwa jest właśnie nadawana.

(2) Nazwy życzeniowe są nakierowane na przyszłość w celu sprawienia, by przyszłość stała się lepsza, są nadawane jako dobry omen.

(3) Nazwy życzeniowe upowszechniają się wraz z rozwojem religii, wraz z przesądami i magią. Opierają się na wierze w magiczną moc języka, na przekonaniu, że słowa czy sposób mówienia mogą przynieść szczęście bądź nieszczęście.

(4) Niektóre nazwy życzeniowe są faktycznie nazwami eufemistycznymi, nadawanymi w celu ukrycia tego, co rzeczywiście istnieje; następuje wtedy udoskonalenie rzeczywistości czy też dokonuje się zapobieżenie trudnościom lub uniknięcie kłopotów.

(5) Niektóre nazwy tego typu mogą być określone jako złowróżbne czy antypochwalne (ang. counter-commendatories). Są to nazwy pejoratywne czy derogatywne, nadawane w celu odwrócenia złej passy i odmienienia złego losu przez sprawienie, że tak nazwane miejsce zostanie uznane przez złe moce lub niszczycielskich intruzów za zbyt nędzne, niegodne uwagi. Takie złowróżbne nazwy pełnią funkcję ochronną.

\section{CHIŃSKIE NAZWY ŻYCZENIOWE}

Chińskie geograficzne nazwy życzeniowe są bardzo liczne i stanowią heterogeniczną kolekcję toponimów (Kałużyńska 2001a: 183-193; 2001b: 140-141; 2002: 181-209). Na potrzeby ich dokładniejszej analizy podzielono je na cztery główne kategorie, odpowiednio do kategorii terminów/wyrazów, z których zostały utworzone. Te cztery kategorie terminów/wyrazów występujących w tych nazwach zostały przez niektórych chińskich badaczy (Chen 1979: 12; Liu 1984: 48-51; Ma 1982: 4-5) określone jako:

(1) jixiangci 吉祥詞 'terminy pomyślne',

(2) chengsongci 稱頌詞 'terminy pochwalne',

(3) qianghuaci 强化詞 'terminy pacyfikacyjne',

(4) xiangrui 祥瑞 'terminy/znaki szczęśliwe, terminy dobrowróżebne'.

Nazwy geograficzne zawierające takie terminy zostały odpowiednio nazwane jak poniżej.

(1) Nazwy pomyślne, jixiang diming 吉祥地名, meiyuan diming 美愿地名, wyrażające pragnienia ludzi dotyczące dobrego życia i zdrowia czy szczęśliwej rodziny, stąd typowe dla nich terminy to: zdrowie, dtugowieczność, dobrobyt, bogactwo, pomyślność, pokój, spokój, np. Funing 阜 息 ‘Obfitość [i] Spokój’, nazwa powiatu w prowincji Jiangsu.

(2) Nazwy pochwalne, songyang diming 公頁扬地名, zawierające terminy określające pożądane cechy charakteru ludzi czy też normy moralnego zachowania 
chińskiego społeczeństwa zgodnie z zasadami konfucjańskimi, takie jak: cnotliwość, obyczajność, prawość, sprawiedliwość, szczerość, zgodność, wykształcenie, np. Xiaoyi 孝義 'Posłuszeństwo Synowskie [i] Sprawiedliwość', nazwa powiatu w prowincji Shanxi.

(3) Nazwy pacyfikacyjne, qianghua diming 强化地名, odzwierciedlające dążenia do zaprowadzenia ,porządku” w społeczności drogą perswazji lub przy użyciu siły zbrojnej. Typowe określenia pacyfikacyjne to ustabilizować, uspokoić, zaprowadzić pokój, zmienić, udoskonalić, ujarzmić. Nazwy te często nadawano po spacyfikowaniu powstania lokalnej ludności czy dokonaniu podboju, stąd często mogły mieć charakter eufemistyczny, świadcząc o hipokryzji dawców, np. Jingde 旌德 'Uhonorować Cnotę', nazwa powiatu w prowincji Anhui, nadana w czasach dynastii Tang (618-906) po spacyfikowaniu lokalnych zamieszek.

(4) Nazwy zabobonne, mixin diming 迷信地名, związane z wiarą w siły nadnaturalne, dobre omeny, bóstwa, duchy itp., zawierające takie określenia, jak: dobry omen, szczęśliwy znak, a także określenia czy też nazwy bóstw i świętych oraz ich atrybutów, stąd można je również nazwać religijnymi.

Materiał badawczy do analizy chińskich geograficznych nazw życzeniowych tworzą przede wszystkim 1973 nazwy jednostek administracyjnych miast i powiatów Chińskiej Republiki Ludowej (ChRL), ustalone do 1986 r. Nazwy życzeniowe, w liczbie 372, stanowią 19\% nazw. Analizowane poniżej bardziej szczegółowo nazwy zabobonne i religijne według przyjętych kryteriów klasyfikacyjnych stanowią w materiale badawczym kategorię nieliczną (10 nazw), chociaż nazw częściowo spełniających kryteria klasyfikacyjne jest znacznie więcej. W analizie dodatkowo wykorzystano materiał nazewniczy pochodzący z innych opracowań toponomastycznych.

\section{NAZWY ZABOBONNE I RELIGIJNE}

Ludzie zabobonni i religijni wierzą w magię, cuda, bogów, bóstwa, duchy, wróżki, diabły itd. Wierzą także, że niektóre przedmioty czy zjawiska są znakami szczęścia, a inne - nieszczęścia. Przesądni ludzie celowo i świadomie nadają swoim siedliskom nazwy, które stanowią pełne nadziei przepowiednie sprowadzające szczęście i dobry los. Nadane nazwy pełnią funkcję dobrego omenu, zapowiadającego przyszłe, pomyślne dla mieszkańców zdarzenia. Ludzie często nazywają swoje siedziby imieniem lub nazwą boga czy świętego (bezpośrednio lub metaforycznie), wierząc, że ów bóg czy święty będzie im sprzyjał, otoczy ich opieką, przeprowadzi przez pełne niebezpieczeństw życie. Na całym świecie występuje wiele nazw, które można określić jako zabobonne czy religijne; mają one związek z kulturą nadających je społeczeństw. 


\section{CHIŃSKIE SYMBOLE ZABOBONNE}

Starożytni Chińczycy byli niewątpliwie ludźmi zabobonnymi. Wyrażali swoje kulturowo nacechowane oczekiwania i pragnienia, używając słów pomyślnych, szczęśliwych (jilihua 吉利話); swój strach przed nieszczęściem i niepowodzeniem okazywali, unikając słów niepomyślnych. Chińskie przysłowie głosi: „Niepomyślne słowa przynoszą niepomyślność, złe słowa przynoszą zło (Shuo xiong ji xiong, shuo huo ji huo 説凶即凶, 説禍即禍)” (Ren 1991: 27).

Chińczycy żyli w świadomości rytmu i zmian przyrody. Uznali, że niektóre zjawiska i obiekty przyrodnicze są dla nich dobre, a inne szkodliwe. Wierzyli, że duszę mają chmury, kamienie, rzeki, góry, zwierzęta i inne obiekty, a także w to, że dusza żyje po śmierci cielesnej. Ich wyobraźnia stworzyła wiele fantastycznych istot. Uważali wiele obiektów za symbole nadnaturalnej mocy.

Obiekty kultu dzieliły się zasadniczo na cztery grupy (Kiang 1935: 272):

(1) duchy nieba, shen 神, jak: słońce, księżyc, gwiazdy, grzmoty, wiatr i deszcz;

(2) duchy ziemi, $q i$ 祗, jak: góry, rzeki, jeziora;

(3) duchy istot ludzkich, gui 鬼, jak: przodkowie, mędrcy, święci, anioły, wielcy mężowie stanu, uczeni czy wojownicy;

(4) duchy rzeczy ożywionych, guai 㤢, jak: smok, feniks, cudowne ptaki, ssaki i gady, święte drzewa i kwiaty, inne obiekty święte i nadnaturalne.

Chińczycy w większości wierzyli, że istnieje wszechmocna i wszechwiedząca Istota i że wszystko, przez co moc i wiedza tej Istoty się manifestują, jest święte, stąd czcić cokolwiek, to czcić Najwyższą Istotę, czcić Boga. Można więc uznać, że starożytni Chińczycy byli monoteistyczni, a zarazem panteistyczni (Kiang 1935: 272).

Znaki dawane ludziom przez Boga były nazywane: furui 符瑞 'znaki pomyślne, pomyślne wpływy, magiczne znaki', jixiang 吉祥 'dobry omen', jiarui 嘉瑞 'pomyślny omen', jiaxiang 嘉祥 ‘pomyślny omen', xiangrui 祥瑞 ‘pomyślny znak, dobry omen', xiangzhao 祥兆 'szczę́liwy omen', xiongxiang 凶祥 'zły omen' (H-Y 1984; Mathews 1963).

Typowym chińskim dobrym omenem było ukazanie się jednej z czterech cudownych istot, siling 四靈 (Eberhard 1986, 1996; Kopaliński 1990):

(1) feng 鳳 lub fenghuang 鳳)凰 'feniks' — symbol wiatru; symbol pięciu najbardziej wartościowych ludzkich cech, takich jak: cnota, obowiązkowość, poprawne zachowanie, humanitaryzm, odpowiedzialność; ptak pojawiający się rzadko, aby zapowiedzieć doniosłe wydarzenie; symbol cesarzowej;

(2) gui 龜 'żółw' - symbol stałości, nieugiętości, długowieczności, wytrzymałości, jego pancerz porównywano do sklepienia niebieskiego, a spód do płaskiej tarczy Ziemi; podpora nieba;

(3) long 龍 'smok' - symbol deszczu i wody, wschodu słońca, płodności, naturalnej męskiej energii; istota dobroczynna; symbol cesarza; 

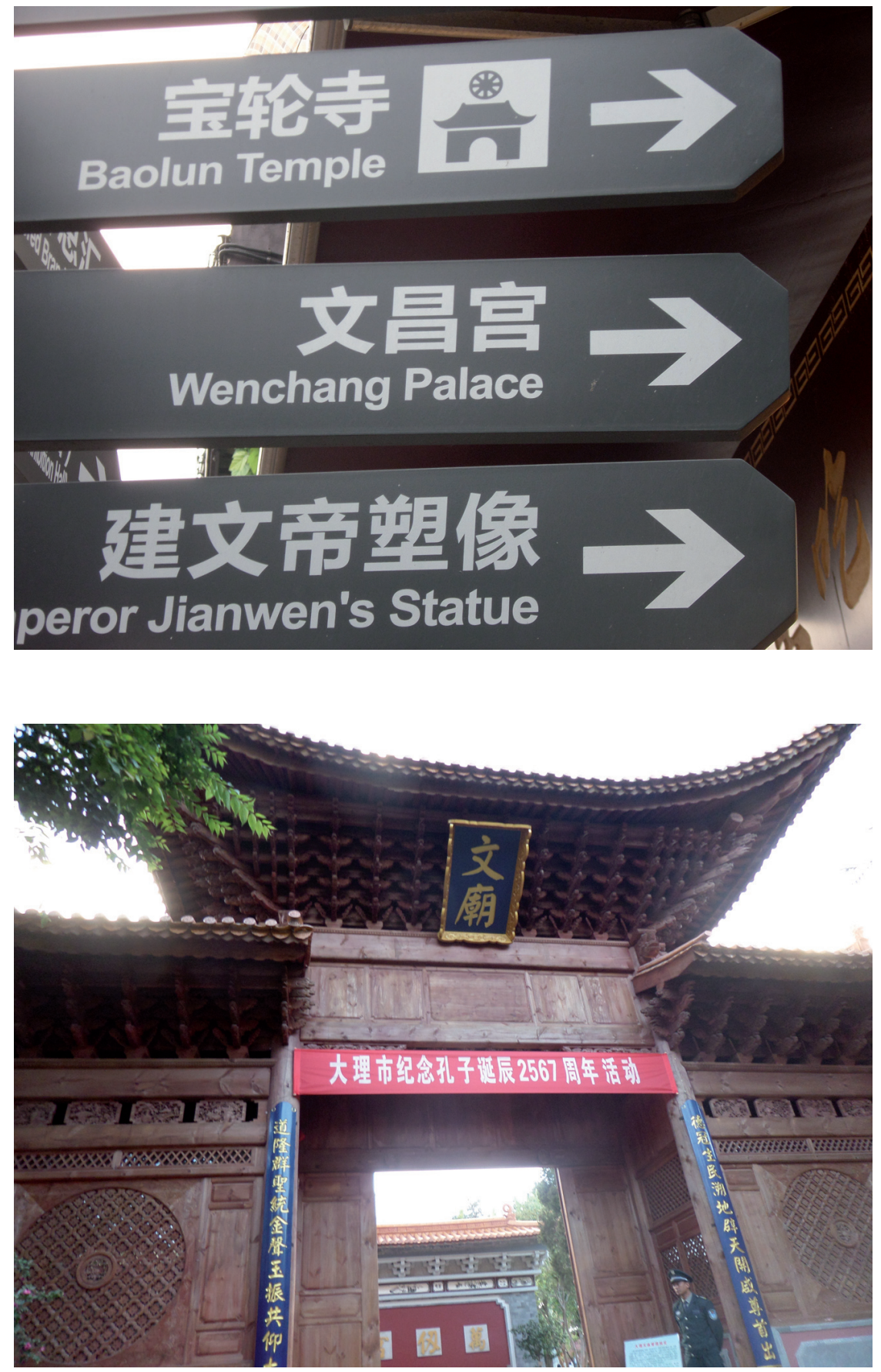
(4) qilin 麒麟 ‘jednorożec’ — symbol dobrej wróżby, życzenie posiadania dzieci, dużej rodziny, dobrze rządzonego państwa, pojawienia się osoby mądrej, sprawiedliwej i świętej; symbol dobroci.

Wiele innych zwierząt, roślin czy obiektów symbolizowało ważne dla społeczeństwa przymioty (Eberhard 1986; 1996), m.in.: długowieczność (cyprys, żuraw, jeleń, góra, kamień, sosna, brzoskwinia), bogactwo (złoto, koń, ryba, nefryt) czy liczne potomstwo (kasztan, granat).

Chińczycy wypracowali równieżjixiang tu'an 吉祥圖案 'obrazki szczęścia, pomyślne wzory'. Pomyślne wzory pochodziły z ilustracji czy też wyobrażeń pomyślnych obiektów i dobrych omenów, wyrażały oczekiwanie szczęścia i dobrego losu, nadzieję na uniknięcie zła (Guo, Han 2000). Umieszczane w różnych miejscach, miały zapewnić pomyślność.

\section{CHIŃSKIE TOPONIMY ZABOBONNE}

Wśród badanych chińskich nazw miejscowych (nazwy jednostek miejskich i powiatów) jest wiele toponimów, w których występują wyżej wymienione określenia, i mogłyby być one uznane za nazwy zabobonne. Nazwy te jednak zgodnie z przyjętymi zasadami klasyfikacji w większości należą do innych kategorii nazewniczych.

Znaczną część takich toponimów stanowią nazwy przeniesione (ang. shift-names), czyli takie, które przeszły z jednego obiektu na inny, bez kreacji formalnojęzykowej. Jedyną zmianą mogło być skrócenie nazwy przez odcięcie jednego z jej członów. Zazwyczaj nazwy miejscowe powstawały z przeniesienia nazwy góry lub rzeki, np.: Fenghuang 鳳凰 ‘Feniks', nazwa powiatu w prowincji Hunan nadana za dynastii Qing (1644-1911), przeniesiona z nazwy pobliskiej góry Fenghuang 鳳凰 'Feniks'. W chińskich rejestrach nazw geograficznych, Zhongguo diminglu 中國地名録 (1983; 1996), można znaleźć 13 innych toponimów, w których człon odróżniający stanowi także Fenghuang 鳳凰 'Feniks'.

Niektóre nazwy wydają się typowymi nazwami zabobonnymi, ale faktycznie są nazwami zestawionymi (ang. combined names), np.: Jiulong 九龍 'Dziewięć Smoków', nazwa powiatu w prowincji Sichuan, nadana w 1926 r.; pochodzi ona stąd, że dziewięć wiosek tworzących powiat miało w nazwie wyraz 'smok'. Nazw z wyrazem 'smok', występującym jako pierwszy człon nazwy, w chińskich rejestrach nazw geograficznych, Zhongguo diminglu 中國地名録 (1983; 1996), jest około 330 .

Są także nazwy miejscowe bezpośrednio związane z pojawieniem się $\mathrm{w}$ danych miejscach dobrych omenów i zaliczone do nazw zabobonnych. Te nazwy mają jednak także dodatkowe motywacje. Należy stwierdzić, że celem nadania takich nazw było po części upamiętnienie tak ważnych wydarzeń, jak przybycie w okolicę istot nadprzyrodzonych — nazwy mogłyby funkcjonować jako nazwy 
okolicznościowo-upamiętniające (ang. commemorative names, incident names), a częściowo - i to uznano za ich cechę najważniejszą - celem nadania takich nazw było wywołanie pomyślności, przyniesienie nadziei i szczęścia (a to funkcja nazw zabobonnych).

Dobrym przykładem toponimów uznanych za nazwy zabobonne jest Jiaxiang 嘉祥 'Pomyślny Omen', nazwa powiatu w prowincji Shandong, powstała w czasach dynastii Jin (1115-1234), upamiętniająca pojawienie się tu dobrowróżbnego jednorożca, co zapowiadało przybycie w te rejony świątobliwego mędrca, dającego nadzieję mieszkańcom na poprawę losu. Inny przykład nazwy zabobonnej to Linyou 麟游 'Jednorożec Wędruje', nazwa powiatu w prowincji Shaanxi, powstała za dynastii Sui (581-618), związana z pojawieniem się w okolicy białego jednorożca symbolu nadziei na lepszą przyszłość.

\section{CHIŃSKIE NAZWY RELIGIJNE}

Trzy wielkie religie Chin to konfucjanizm, taoizm i buddyzm, przy czym ten pierwszy stanowił przede wszystkim nurt filozoficzno-etyczny, a stał się rodzajem religii państwowej.

Specyficzne zjawiskio w starożytnej cywilizacji chińskiej polegało na tym, że polityka, filozofia, edukacja i religia, a szczególnie edukacja i religia (nazywane tym samym terminem jiao 教 'nauczanie, instruowanie') tworzyły praktycznie jedno (Kiang 1935: 276).

Z myślą Konfucjusza (551-479 r. p.n.e.) powiązanych jest większość koncepcji chińskiej etyki społecznej, zasad moralnych, reguł zachowania jednostki w społeczności, a także podstawy funkcjonowania państwa i rządzących. Konfucjanizm stał się specyficzną religią państwową, w myśl której rząd centralny był czymś w rodzaju najwyższej katedry, publiczne szkoły stanowiły kaplice, cesarz i panowie feudalni stali się prymasami, a ministrowie, administratorzy i nauczyciele biskupami i księżmi. Starożytne teksty funkcjonujące jako podręczniki edukacyjne (w tym dzieła przypisywane Konfucjuszowi) stały się biblią religii państwowej, a wszyscy mądrzy władcy oraz bohaterowie narodowi zostali bóstwami i świętymi (Kiang 1935: 276). Oficjalne ofiary składano przodkom, świętym i bóstwom, Niebu, Księżycowi, górom i rzekom. Konfucjusz pozostał jednak na zawsze Wielkim Nauczycielem i Mędrcem, któremu oddawano cześć ludzką.

Konfucjańskie koncepcje państwa, ładu społecznego i idealnego społeczeństwa przedostały się również do chińskiego nazewnictwa geograficznego, przede wszystkim do omawianych tu nazw życzeniowych, a szczególnie nazw pochwalnych. Celem nadawania takich nazw było popularyzowanie wśród ludności społecznie aprobowanych form zachowania, wartości społecznej roli i statusu jednostki, kultywowanie właściwych cech moralnych i postaw obywatelskich. Dawcy takich nazwy 
próbowali wzmocnić harmonię społeczną, osiągnąć przyszłe moralne i polityczne cele. Ten rodzaj toponimów został wprowadzony w czasach Wschodniej Dynastii Han (25-200) i stał się później coraz bardziej powszechny (Kałużyńska 2001a: 183-193; 2001b: 140-141; 2002: 181-209).

Dwie pozostałe wielkie religie w Chinach, rodzimy taoizm i importowany buddyzm, odmawiały wartości światu pozornemu i odwoływały się do mistycznej części ludzkiej natury. To do tych religii sięgali wierzący Chińczycy, spragnieni cudowności i nadziei. Buddyzm dawał nadzieję nirwany i wiecznego szczęścia. Taoizm obiecywał osiągnięcie nieśmiertelności, zalecał samodoskonalenie organizmu, a także włączał wiarę w czary, zaklęcia, magiczne formuły i uroki. Te dwie religie dopełniały konfucjańską religię państwową. Można było w życiu publicznym być konfucjanista, a w życiu prywatnym taoistą czy buddystą. Jest to wyraz chińskiego eklektyzmu religijnego.

Wśród chińskich toponimów można znaleźć wiele przykładów nazw religijnych, zawierających nazwy bogów, bóstw, bodhisattwów, świętych itp. W chińskich rejestrach nazw geograficznych, Zhongguo diminglu 中國地名録 (1983; 1996), znajduje się 17 toponimów z nazwą bodhisattwy Guanyin (Awalokiteśwara), uznanej w Chinach za boginię miłosierdzia. Nazwy te najwyraźniej nadano jako prośby o pomoc i wsparcie dla cierpiących.

Nazwy buddyjskie czy taoistyczne nadawano przede wszystkim świątyniom, obiektom topograficznym, małym miejscowościom przyświątynnym, wioskom. Wśród badanych nazw miejscowych miast i powiatów nie znaleziono takich nazw.

\section{PODSUMOWANIE}

Podział chińskich nazw życzeniowych na nazwy pomyślne, pochwalne, zabobonne czy pacyfikacyjne czasami wydaje się dość sztuczny. Jest wiele nazw składających się z terminów należących do różnych kategorii, np. nazwy składające się z „terminu pomyślnego” i „terminu pochwalnego”, jak Anren 安仁 ‘Spokojny i Humanitarny', nazwa powiatu w prowincji Hunan, nadana w czasach dynastii Tang (618-906). Podział ten jednak okazuje się pomocny w dokładniejszej analizie tej heterogenicznej kolekcji nazw.

Liczne kategorie nazw życzeniowych są szeroko reprezentowane w materiale badawczym. Te nazwy, nadane w celu wywołania pomyślnych skutków czy osiągnięcia istotnych przyszłych politycznych czy moralnych celów, ujawniają, co Chińczycy uważali za „dobre” i czego dotyczyły ich nadzieje na „lepszą” przyszłość. Ukazują różne sfery zainteresowań i oczekiwań chińskiego społeczeństwa. Ogólnie ujmując, sprowadzają się one do dwóch podstawowych kategorii: oczekiwań dotyczących „szczęścia” osobistego i społecznego oraz oczekiwań dotyczących moralnej doskonałości jednostki i społeczeństwa. Nazwy życzeniowe pojawiły się we wczesnych 
fazach chińskiej cywilizacji i nadal stanowią jedną z najbardziej typowych kategorii chińskich toponimów.

Znaczna liczba chińskich nazw życzeniowych została dostrzeżona przez niektórych zachodnich badaczy. J. E. Spencer stwierdził:

Niektóre chińskie nazwy miejskie sprawiają wrażenie, że zostały wybrane jako pełne nadziei proroctwo. Czasem wydarzenia spełnily tę nadzieję, czasem nie [With some Chinese cities one has the feeling that their names were chosen in hopeful prophecy. Sometimes events have fulfilled the hope, sometimes they have not] (1941: 94).

Najwyższe idee i pragnienia rzadko zostają urzeczywistnione, a jednak ludzie wciąż mają nadzieję...

\section{LITERATURA}

Chen G. 1979: Woguo gudai diming gailun [Wstępne informacje o starożytnych chińskich toponimach], „Diming zhishi” [Wiedza o toponimach] 1, s. 1-15, 48.

Chen Z. 1982: Zhongguo wenhua dili [Chińska geografia humanistyczna], Muduo Chubanshe, Taibei.

Eberhard W. 1986: A Dictionary of Chinese Symbols, przeł. G. L. Campbell, Routledge \& Kegan Paul, London-New York.

Eberhard W. 1996: Symbole chińskie. Stownik, przeł. R. Darda, Universitas, Kraków.

Guo F., Han C. 2000: Zhongguo de jixiang tu'an [Chińskie ilustracje dobrowróżebne], „Zhongguo wenxue" [Chińska literatura] 1, s. 113-115.

H-Y 1984: Han-Ying cidian [Słownik chińsko-angielski], Shangwu Yinshuguan, Beijing.

Kałużyńska I. 2001a: Wishful Thinking and Chinese Place Names, „Rocznik Orientalistyczny” LIV, 2, s. $183-193$.

Kałużyńska I. 2001b: Wspótczesne chińskie nazwy miejscowe (nazwy miast i powiatów) - cechy strukturalne i semantyczne, „Onomastica” XLVI, s. 123-144.

Kałużyńska I. 2002: Contemporary Chinese Place Names. Names of Administrative Divisions at County and City Level, „Schweizer Asiatische Studien. Monographien” 33, Peter Lang AG, Bern itd.

Kiang K. 1935: Chinese Civilization. An Introduction to Sinology, Chung Hua Book Co, Shanghai.

Kopaliński W. 1990: Stownik symboli, Wiedza Powszechna, Warszawa.

Liu S. 1984: Dimingxue ruogan lilun wenti de tantao [Rozważanie na temat kilku teoretycznych zagadnień toponomastycznych], „Dimingxue Yanjiu” [Badania toponomastyczne] 1, s. 45-55.

Liu W. 1979: Shanxi diming shili [Badania toponimów prowincji Shanxi], „Diming zhishi” [Wiedza o toponimach] 1, s. 16-22.

Ma Y. 1982: Diming de texing jiqi zai dili zhitu zhong de yingyong [Specyficzne cechy toponimów i ich wykorzystanie w opracowywaniu map], „Diming zhishi” [Wiedza o toponimach] 1, s. 2-5; 2, s. 4-8.

Mathews R. H. 1963: Chinese-English Dictionary, Harvard University Press, Cambridge, Massachussetts.

Ren P. 1991: Yuyan jinji [Tabu językowe], „Duzhe wenzhai” [Wybór tekstów czytelnika] 12, s. 26-28. Spencer J. E. 1941: Chinese Place Names and the Appreciation of Geographic Realities, „Geographer Review", 31, s. 79-94.

Stewart G. R. 1970: American Place Names. A Concise and Selective Dictionary for the Continental United States of America, Oxford University Press, New York, s. XVII-XXXIII. 
Stewart G. R. 1975: Names on the Globe, Oxford University Press, New York. TNEB 1974: The New Encyclopaedia Britanica, 12, Names, s. 814-819.

TNEB 1994: The New Encyclopaedia Britanica, 24, Names, s. 733-738.

ZD 1983: Zhongguo diminglu (Gazeteer of China), Ditu Chubanshe, Beijing.

ZD 1997: Zhongguo diminglu (Gazeteer of China), Ditu Chubanshe, Beijing.

\section{CHINESE RELIGIOUS AND SUPERSTITIOUS NAMES}

\section{SUMMARY}

In the Chinese culture the relationship between the name and the reality was predominantly regarded neither as formal nor ideal, but as real and very important. The approach to names as to real facts caused that the Chinese very often expressed their culture-oriented desires by deliberately forming names for the idea they wanted them to symbolize. Many geographical names have been consciously bestowed in order to create a good (from the point of view of the name-giver) effect in the future. Such names are generally termed as wishful names, commendatory names or benedictory names. Among them, on the basis of the Chinese place-name material, it is possible to distinguish several different groups: auspicious names, religious and superstitious names, eulogizing names and pacifying names. This paper briefly analyses Chinese names connected with three great religions in China (Confucianism, Taoism, Buddhism) and superstitious names connected with the belief in supernatural forces, gods and good omens.

Keyw ord s: Chinese superstitious and religious place names, Chinese wishful place names, Chinese toponymy 